\title{
Deteksi Antibodi Brucella pada Sapi Perah di Kecamatan Purwoharjo Kabupaten Banyuwangi dengan Metode Rose Bengal Test (RBT)
}

\author{
(DETECTION OF ANTIBODY BRUCELLA IN DAIRY COW IN PURWOHARJO \\ DISTRICT, BANYUWANGI REGENCY USING ROSE BENGAL TEST METHOD \\ $(\mathrm{RBT}))$
}

\author{
Welyanto Kurniawan Dwi ${ }^{1 *}$, Wiwiek Tyasningsih ${ }^{2}$, Ratih Novita Praja ${ }^{2}$, Iwan Sahrial \\ Hamid $^{3}$, Suryanie Sarudji ${ }^{2}$, Muhammad Thohawi Elziyad Purnama ${ }^{4}$ \\ ${ }^{1}$ Bachelor of Veterinary Medicine, \\ ${ }^{2}$ Department of Veterinary Microbiology, \\ ${ }^{3}$ Department of Basic Veterinary Science, \\ ${ }^{4}$ Department of Veterinary Anatomy, \\ Faculty of Veterinary Medicine, Universitas Airlangga, \\ UNAIR C-Campus Mulyorejo, Surabaya, Jawa Timur, Indonesia, 60115 \\ Telp. (031)5993016, Fax. (031)5993015 \\ *Corresponding author: welyanto.k.d-2014@ @kh.unair.ac.id
}

\begin{abstract}
Abstrak
Penelitian ini bertujuan mengetahui keberadaan antibodi dari bakteri brucella pada sapi perah di Kecamatan Purwoharjo Kabupaten Banyuwangi menggunakan Rose Bengal Test (RBT). Metode yang digunakan dalam penelitian ini adalah metode analisis diskriptif dengan pendekatan kuantitatif, yaitu metode yang menggambarkan keberadaan antibodi Brucella pada sapi perah dengan cepat. Informasi pendukung diperoleh dari survei peternak dengan teknik wawancara. Sampel ditentukan dengan rumus slovin dengan ukuran sampel sebanyak 75 sampel dari 294 ekor sapi pada populasi sapi perah di Kecamatan Purwoharjo. Hasil penelitian menunjukan 2 sampel dinyatakan positif Brucella dari 75 sampel. Hasil penelitian ini dapat disimpulkan bahwa reaktor Brucella ditemukan pada sapi perah di Kecamatan Purwoharjo Kabupaten Banyuwangi yang berpotensi menyebabkan penyakit Brucellosis. Harapan dari penelitian ini adalah data yang diperoleh dapat diuji ulang dan diuji lebih lanjut dalam penelitian selanjutnya sehingga hasil dapat dikonfirmasi.
\end{abstract}

Kata kunci: Brucellosis, sapi perah, Rose Bengal Test, Banyuwangi

\section{Abstract}

The purpose of this study was to detect the presence of antibodies of the bacteria Brucella in dairy cows in the District Purwoharjo Banyuwangi using the Rose Bengal Test (RBT). The method used in this research was a descriptive analysis method with a quantitative approach, was a method that describes the presence of Brucella antibodies in dairy cows quickly. Supporting information obtained from the survey of farmers using interviews. The sample was determined by the formula slovin with a sample size of 75 samples from 294 cows in the dairy cow population of the District Purwoharjo. The results show 2 samples considered positive Brucellosis from 75. The results of this study can be concluded that the reactor Brucella found in dairy cattle in the district of Banyuwangi Purwoharjo that can potentially cause disease Brucellosis. Expectations from this study were the data obtained can be re-tested and further testing in future studies so that results can be confirmed.

Key words: Brucellosis, dairy cattle, Rose Bengal Test, Banyuwangi

\section{PENDAHULUAN}

Brucellosis merupakan penyakit zoonosis dan tergolong penyakit endemik di beberapa wilayah di dunia, termasuk Eropa Mediterania,
Afrika Utara dan Sub Sahara, Timur Tengah, Asia Tenggara dan banyak negara Amerika Selatan. Brucellosis dianggap sebagai salah satu zoonosis utama yang ditularkan melalui kontak langsung pada hewan, mengkonsumsi susu dan 
produk susu (Sharma et al., 2016). Berdasarkan data yang diperoleh dari BBVet Wates tahun 2017 situasi kejadian Brucellosis di Pulau Jawa hanya ditemukan di kota Kendal, Sleman, dan semarang. Prevalensi Brucellosis yang telah dilakukan penyidikan di Regional IV oleh Balai Besar Veteriner Wates dari tahun-ketahun masih cukup fluktuatif, Provinsi Jawa Tengah rata-rata dari tahun 2010-2014 sebesar: 0.9\% (237/26.192), DIY 1.19\% (110/9.224) dan Jawa Timur 3.1\% (1.022/32.964), sehingga prioritas untuk pengendalian penyakit Brucellosis adalah di Jawa timur. Jawa timur merupakan provinsi yang memiliki jumlah ternak sapi perah yang cukup banyak dimana terdapat 265.002 ekor yang tersebar di setiap daerah pada tahun 2016. Menurut data dari Dinas Peternakan Provinsi Jawa Timur Tahun 2016 terdapat 11 kabupaten yang dinilai unggul dalam jumlah ternak sapi perah yang dimiliki diantaranya Pasuruan, Malang, Mojokerto, Sidoarjo, Jombang, Kediri, Blitar, Tulung agung, Trenggalek, Jember, dan Banyuwangi (Dinas Peternakan Provinsi Jatim, 2016).

Banyuwangi merupakan salah satu Kabupaten yang unggul dalam jumlah ternak sapi perah meskipun dari 11 Kabupaten yang dinilai unggul jumlah ternak sapi perah di Banyuwangi memiliki Populasi yang sedikit yaitu terdapat 729 ekor. Populasi sapi perah yang sedikit ini mengakibatkan Kabupaten Banyuwangi kurang diperhatikan terhadap pengontrolan dan pengawasan penyebaran penyakit Brucellosis (Dinas Pertanian Kab. Banyuwangi, 2017). Berdasarkan kondisi tersebut maka peneliti ingin melakukan deteksi untuk mengetahui adanya antibodi terhadap bakteri Brucella sp. yang dapat menyebabkan penyakit Brucellosis pada ternak sapi perah di Kecamatan Purwoharjo Kabupaten Banyuwangi dengan metode Rose Bengal Test (RBT).

\section{METODE PENELITIAN}

Penelitian ini dilakukan dalam 2 tahap yaitu pengambilan sampel darah pada sapi perah dan pengujian serologis. Pengambilan sampel darah sapi perah dilakukan di Kecamatan Purwoharjo
Kabupaten Banyuwangi sedangkan pengujian serologis dilakukan di Laboratorium Mikrobiologi PSDKU UNAIR di Banyuwangi. Sampel yang diteliti sebanyak 75 sampel.

Alat dan bahan yang digunakan dalam penelitian ini adalah tabung vakutainer non EDTA, kertas lebel, dan jarum venoject $21 \mathrm{G}$, aluminium foil, tremos es, spuit (Terumo) ukuran 18 G, mikroplate, mikropipet, tusuk gigi, mikrotube, desinfektan, kapas, alkohol, kit RBT (antigen Brucella Rose Bengal, serum kontrol positif dan kontrol negatif.

Rancangan penelitian ini menggunkan metode diskriptif dengan pendekatan kuantitatif yaitu suatu penelitian yang memberikan gambaran secara sistematis dan faktual tentang fakta-fakta mengenai ada dan tidaknya antibodi Brucella yang ditemukan pada sapi perah. Keberadaan antibodi Brucella $s p$. diuji dan dideteksi dengan menggunakan metode aglutinasi pada pengujian serologis RBT (Sugiyono, 2009). Prosedur penelitian dilakukan dengan cara mereaksikan antara serum darah sapi perah dan antigen RBT yang kemudian dilakukan homogenisasi dengan cara menggoyangkan serum dan antigen selama 4 menit hingga terjadi proses aglutinasi (OIE, 2009).

\section{HASIL DAN PEMBAHASAN}

Jumlah sampel serum darah yang telah didapatkan dari 14 peternak sapi perah di 11 Desa di Kecamatan Purwoharjo sebanyak 75 sampel selama bulan Desember 2017 dapat. Hasil pengujian serologis terhadap 75 sampel darah yang diambil di Kecamatan Purwoharjo dengan menggunakan metode Rose Bengal Test (RBT) telah diuji dan terdapat 2 sampel yang dinilai positif Brucella berdasarkan pemeriksaan dengan menggunakan antigen Brucella yang digunakan menunjukan tanda-tanda penggumpalan yang jelas. Rose Bengal Test merupakan Rapid Test yang sering digunakan untuk mendeteksi adanya antibodi terhadap antigen Brucella sp. dengan cara mencampur serum darah ternak yang diduga terinfeksi dengan antigen Brucella sp. Rose Bengal Test 
merupakan uji serologis yang mudah dikerjakan, uji ini akan membentuk reaksi antara antigen Brucella sp. terhadap serum darah yang mengandung antibodi Brucella sp. (OIE, 2009). Antigen Brucella yang digunakan pada pemeriksaan RBT adalah antigen Brucella yang memiliki koloni smooth yang diwarnai dengan Rose Bengal, dengan larutan penyangga sampai dengan $\mathrm{pH} 3,65$. Kondisi $\mathrm{pH}$ netral pada uji RBT dapat mengukur keberadaan IgM dan IgG. Rose Bengal Test yang memiliki kadar $\mathrm{pH}$ 3,65 dapat mencegah aglutinasi dengan IgM dan tampaknya hanya mengukur IgG (Kaltungo et al, 2014). $\mathrm{Ph}$ 3,65 dari antigen RBT dan mengakibatkan inaktivasi dari $\operatorname{IgM}$ sementara dan hanya meninggalkan antibodi Brucella utuh IgG sehingga pada pengujian RBT yang di uji adalah titer antibodi dari IgG yang bereaksi dengan antigen dari RBT yang dapat menimbulkan rekasi aglutinasi (Klein, 1991).

Hasil pengujian Rose Bengal Test (RBT) yang telah dilakukan diperoleh 2 sampel serum yang dinilai positif yaitu sampel Sapi 12.1 dengan kode 3484 dan 12.2 dengan kode 3483 .

Hasil pemeriksaan positif pada uji RBT didapatkan pada sapi yang berjenis Friesien Holstein dengan umur 4 tahun dan berjenis kelamin betina dimana sesuai dengan riwayat yang telah diperoleh dari pemilik sapi bahwa sapi perah yang mengalami keguguran pada usia kehamilan 5 bulan dan 8 bulan belum pernah dilakukan vaksinasi. Faktor yang dapat mempengaruhi hasil positif dari pemeriksaan yang telah dilakukan adalah pernah dilakukan proses vaksinasi, infeksi dari kasus abortus, pemeriksaan kesehatan yang kurang baik dan kurangnya pengetahuan peternak mengenai kasus Brucellosis. Antibodi terhadap bakteri Brucella dapat ditemukan di dalam tubuh sapi perah karena adanya infeksi melalui perkawinan alami dengan sapi jantan. Sapi jantan yang terinfeksi bakteri Brucella dapat menularkan penyakit melalui semen yang dikeluarkan melalui perkawinan alami yang dilakukan (Noakes et al., 2009).

Pengujian sampel serum darah dengan menggunakan reagen RBT didapatkan hasil positif pada serum yang diambil dari ke 2 sapi perah di Kecamatan purwoharjo, dimana terjadi penggumpalan pada serum darah yang dicampur dengan reagen RBT dan membentuk suatu gumpalan halus seperti pasir. Hasil positif yang diperoleh dari pugujian 2 serum darah sapi dengan kode 3484 dan 3483. Hasil yang diperoleh menunjukan bahwa serum dan antigen menunjukan reaksi positif ++ pada serum darah sapi dengan kode 3484 yang ditunjukan dengan adanya agultinasi berupa pasir halus dengan cairan agak jernih dan batas jelas sedangkan pada serum darah sapi dengan kode 3483 menunjukan reaksi positif + yang ditunjukan dengan adanya aglutinasi berupa pasir halus dengan cairan tidak jernih dan batas tidak jelas.

Antibodi anti-Brucella (IgM dan IgG) adalah protein yang menyebabkan aglutinasi, fiksasi komplemen, dan presipitasi saat bereaksi dengan antigen homolognya yang berasal dari Bakteri Brucella. Antibodi IgM adalah antibodi yang pertama kali muncul ketika terjadi infeksi terhadap ternak dan bertambah jumlahnya secara bertahap terhadap kasus infeksi akut. Antibodi IgM dapat diperoleh dari hewan yang telah dilakukan proses vaksinasi karena pada proses vaksinasi akan merangsang sistem imun untuk menghasilkan antibodi. Berbeda dengan Antibodi IgG yang kemudian muncul setelah onset infeksi berakhir dan dipicu oleh protein sitoplasma dari Brucella yang tidak dapat difagosit oleh makrofag sehingga bakteri akan tetap berada dalam tubuh atau jaringan organ tubuh dan melakukan perkembangbiakan secara intraseluler. Berdasarkan dasar ini maka pengujian serologis yang dilakukan didasarkan pada antibodi IgG untuk membedakan antara host yang terinfeksi dan yang tidak terinfeksi (Mohamed, 2015). Antibodi terhadap Brucella memiliki potensi untuk bereaksi silang dengan antibodi yang terdapat pada beberapa bakteri enterik. Reaksi silang dalam aglutinasi serum telah diamati pada infeksi yang disebabkan oleh beberapa bakteri enterik sehingga reaktivitas silang dapat menghambat interpretasi banyak tes serologis yang digunakan dalam diagnosis Brucellosis. Situasinya diperparah pada hewan ternak yang divaksinasi dengan vaksin yang membuat sulit untuk membedakan antara hewan 
yang divaksinasi dan yang terinfeksi (Liang, 2010).

Bakteri Brucella abortus merupakan bakteri yang sering menginfeksi pada sapi bersifat parasit intraseluler atau parasit obligat karena bakteri ini mengalami proses perkembangbiakan di dalam sel dan berkemampuan untuk menginvasi semua jaringan hewan sehingga dapat menyebabkan bermacam-macam infeksi (Todar, 2008). Sumber utama penularan Brucella pada sapi diantaranya sekresi cairan uterus ,jaringan placenta , janin, kolostrum dari susu penderita atau semen beku yang tercemar Brucella (Supartono, 2004).

Fase bakterimia terjadi setelah sapi mengkonsumsi bahan makanan yang tercemar dan menyebabkan kuman menyebar dan menetap pada organ tubuh melalui pembuluh darah dan limfe. Sapi yang sedang bunting akan memproduksi eritritol dalam jumlah banyak, sehingga B. abortus akan lebih cepat berkembang dalam uterus sapi bunting tersebut. Akibatnya akan terjadi radang dinding uterus dan radang plasenta, sehingga dapat mengganggu pengiriman bahan makanan dari induk ke embrio atau fetusnya. Gangguan pertumbuhan yang timbul pada pedet dapat berupa mati dini, lahir lemah, atau cacat (Ratih, 2014).

Zat eritritol merupakan zat kimia yang disukai oleh bakteri Brucella dan dengan adanya zat ini bakteri Brucella dapat bertahan hidup dan melakukan perkembangbiakan terutama pada endometrium dan pada ruang diantara kotiledon. Bakteri dapat ditemukan pada vili, ruang diantara vili dan membran plasenta yang memperlihatkan warna gelap atau merah tua. Perkembangbiakan bakteri Brucella pada uterus menyebabkan infeksi yang berdampak abortus. Abortus dapat terjadi karena rapuhnya pertautan plasenta fetalis dengan plasenta maternalis sehingga terpisah sebagai akibat bersarannya bakteri Brucella di dalam uterus. Setelah abortus 2-3 kali biasanya infeksi menjadi menetap atau kronis, tidak memperlihatkan tanda-tanda klinik dan sapi yang bersangkutan dapat kembali bunting normal akan tetapi sapi-sapi demikian tubuhnya terus menerus mengeluarkan kuman
Brucella (carrier) yang bersifat patogen bagi sapi lain maupun bagi manusia (Djaenudin, 2013). Hasil positif diperoleh dari respon serologik pasca infeksi pada infeksi alami akan muncul setelah 2 sampai 4 minggu. Invasi bakteri pada uterus yang bunting akan menghasilkan antibodi dalam jumlah besar dan berlangsung terus menerus (Celli et al., 2003).

Proses pembentukan antibodi pada kasus infeksi Brucella dimulai dengan masuknya bakteri Brucella kedalam tubuh melalui pembuluh darah dan akan merangsang respon imun untuk melepaskan monosit yang berfungsi untuk memfagosit bakteri. Makrofag/Antigen Precenting Cell (APC) yang telah memfragmentasi antigen akan mempresentasikan fragmen antigen tersebut kepada sel limfosit $\mathrm{T}$ helper (sel Th) melalui molekul Major Histocompatibility Complex (MHC) kelas II yang terletak dipermukaan monosit. Sel Th berinteraksi dengan APC melalui Cluster of Differentiation (CD4) dan T-cell Receptor (TCR) yang dimiliki oleh Th. Selanjutnya akan terjadi aktivasi sel Th, sel Th berproliferasi dan mengeluarkan sitokin (interleukin-1/IL-1) yang akan mengaktivasi sel B menjadi sel plasma yang siap memproduksi antibodi spesifik terhadap antigen Brucella sp. (Starr et al., 2008).

Respon humoral pada awal infeksi akan diproduksi antibodi terhadap antigen Brucella $s p$. di dalam tubuh. Secara umum antibodi yang dihasilkan oleh sapi yang mengalami proses vaksinasi atau infeksi alami ditemukan dalam 3 jenis yaitu $\operatorname{IgM}, \operatorname{IgG}_{1}$ dan $\operatorname{IgG}_{2}$. Setelah enam bulan, $\mathrm{IgG} 2$ biasanya hilang, namun kadar IgM dan IgG1 masih tetap ada meskipun dalam jumlah yang rendah, pada kejadian infeksi yang menahun atau dalam kurun waktu yang lama kadar antibodi $\mathrm{IgG}_{1}$ lebih tinggi dari kadar antibodi IgM (Neta et al., 2010).

\section{KESIMPULAN}

Hasil penelitian deteksi antibodi Brucella pada sapi perah di Kecamatan Purwoharjo Kabupaten Banyuwangi dengan metode Rose Bengal Test (RBT) disumpulakan bahwa ditemukannya reaktor bakteri Brucella pada sapi 
perah di Kecamatan Purwoharjo yang diperoleh dengan terjadinya reaksi aglutinasi berupa pasir halus dengan batas yang jelas akibat ikatan antara antigen Rose Bengal Test dan antibodi Brucella. Sampel yang dinyatakan positif Brucellosis sebesar 3\% dari total sampel yang telah diambil yaitu 2 sampel dari 75 sampel yang telah diteliti.

\section{UCAPAN TERIMA KASIH}

Peneliti mengucapkan terima kasih kepada Dinas Pertanian Kabupaten Banyuwangi dan PSDKU Banyuwangi Universitas Airlangga atas izin yang diberikan dan fasilitas untuk melaksanakan penelitian.

\section{DAFTAR PUSTAKA}

Balai Besar Veteriner (BBVet) Wates. 2017. Peta Regional Penyakit Hewan dan Kesmavet Periode Bulan Januari-Maret Tahun 2017. Yogyakarta.

Celli, J., C.D. Chastellier, D. Franchini, J. Pizarro-cerda, E. Moreno, and J. Gorvel. 2003. Brucella Evades Macrophage Killing via VirB-dependent Sustained Interactions with the Endoplasmic Reticulum, 198(4).

Dinas Pertanian Kabupaten Banyuwangi. 2017. Rekap Populasi Ternak Per Wilayah (ekor). Dinas Pertanian Kabupaten Banyuwangi. Banyuwangi.

Dinas Peternakan Provinsi Jawa Timur. 2016. Data Jumlah Populasi Ternak di Provinsi Jawa Timur. Laporan Tahunan. Surabaya. //http.Disnak.Jatimpro.go.id/Data

Statik/Populasi ternak di Jawa Timur (15 Desember 2017).

Djaenudin, G. dan Z.A. Riza. 2013. Cendawan Penyebab Abortus Dalam Alat Reproduksi Sapi Betina. Balai Besar Penelitian Veteriner. J Bio, 12(2).
Arruda R. P., B. A. Ball., C. G. Gravance., A. R. Garcia., and I. K. K. Liu. 2002. Effects of Extenders and Cryoprotectants on Stallion Sperm Head Morphometry. Theriogenol, 58: 253-256

Kaltungo, B.Y., S.N.A. Saidu, A.K.B. Sacey, and H.M.A. Kazeem. 2014. Review on Diagnostic Techniques for Brucellosis. African J Bio, 13: 1-10.

Beletti, M. E., L. Da Fontoura Costa and M. P. Viana. 2004. A comparison of Morphometric Characteristic of Sperm From Fertile Bos taurus and Bos indicus Bulls in Brazil. Anim Repro Sci, 85: 105-116.

Klien, G.C., K.A. Behan. 1991. Determination of Brucella Immunoglobulin $\mathrm{G}$ Agglutinating Antibody Titer with Dithiothretol. J Clin Microbiol, 14(1): 24-25.

Liang, L., D. Leng, C. Burk, R.N. Sasaki, M.A. Kayala, V.L. Atluri, J. Pablo, B. Unal, T.A. Ficht, E. Gotuzzo, M. Saito, W.J. Morrow, X. Liang, P. Baldi, R.H. Gilman, J.M. Vinetz, R.M. Tsolis, P.L. Felgner. 2010. Large scale immune profiling of infected humans and goats reveals differential recognition of Brucella melitensis antigens. PloS Negl Trop, 8(4): 673-675.

Mohamed, G.E., A.A. Alwaleed, and A.A. Abdullah. 2015. Host Response to Brucella Infection : Review and Future perspective. $J$ Infect Dev Ctries, 9(7): 697-701.

Neta, A.V.C., J.P.S. Mol, M.N. Xavier, T.A. Paixao, A.P. Lage, R.L. Santos. 2010. Pathogenesis of Bovine brucellosis. J Vet, 184: 146-155.

Noakes, D.E., T.J. Parkinson and G.C.W. England. 2009. Arthur's Veterinary Reproduction and Obstetrics Ed. W. B Saunders Co. Philadelphia. p483-486. 
Office International des Epizooties (OIE). 2009.

Bovine Brucellosis. Manual of Diagnostic Test and Vaccines for Terrestrial Animals. Paris. 4(3): 564-567.

Ratih R., D. Handijatno, Suwarno, dan F.A. Rantam. 2014. Determinan Antigen Gen omp2a Brucella abortus Isolat Lokal. Fakultas Kedokteran Hewan. ACTA Vet Indonesia, 2(1): 17-25.

Sharma, H.K., S.K. Kotwal, D.K. Singh, M.A. Malik, A. Kumar, R. Gunalan, and M. Singh. 2016. Seroprevalence of Human Brucellosis in and Around Jammu, India, Using Different Serological Tests. Vet World, 9(7): 42-46.
Sugiyono. 2009. Metode Penelitian Kuantitatif, Kualitatif, dan R\&D. Bandung. Alfabeta.

Supartono. 2004. Isolasi dan Identifikasi Brucella abortus penyebab keguguran pada sapi. Prosiding Temu Teknis Nasional Tenaga Fungsional Pertanian. Balai Penelitian Veteriner. Bogor.

Starr, T., T.D. Wherly, L.A. Knodler, J. Celli. 2008. Brucella intercellular replication requires trafficking through the late endosomal/lysosomal compartment. Traficc. Pub Med, (9): 678-694.

Todar, K. 2008. Textbook of Bacteriology. University of Wisconsin. Science Magazine. p304. 